\title{
Current Status in Quality of Treated Wastewater for Potential Reuse Scheme in Ruai, Nairobi County, Kenya
}

\author{
Gerald Irungu Maina $^{1^{*}} \quad$ Maarifa Ali Mwakumanya ${ }^{2} \quad$ Andrew Wekesa Wamukota ${ }^{1}$ \\ 1.Department of Environmental Studies (Community Development), Pwani University, P.O. Box 195- 80108, \\ Kilifi, Kenya \\ 2.Department of Environmental Science, Pwani University, P.O. Box 195- 80108, Kilifi, Kenya
}

\begin{abstract}
The research is self-sponsored
Abstract

The study examined the current status in quality of the treated wastewater (TWW) discharged at Dandora Estate Sewage Treatment Works (DESTW) in Ruai with a view to assessing its reuse potential and conformity to the national standards recommended for safe use. The DESTW discharges approximately $80,000 \mathrm{~m}^{3} /$ day of TWW through its three outlets into the adjacent Nairobi River without any planned use option. However, some people use it directly or indirectly for their livelihoods oblivious of its quality status, putting at risk their own health, public health and the environment. Understandably, with freshwater becoming increasingly scarce, thus limiting livelihood options, water planners and users are forced to reconsider other water resources such as wastewater which can be used both economically and effectively. Samples of TWW were collected from the three outlets (sampling sites) at DESTW, prepared and analysed for heavy metals [lead $(\mathrm{Pb})$, zinc $(\mathrm{Zn})$, copper $(\mathrm{Cu})$, cadmium $(\mathrm{Cd})$, chromium $(\mathrm{Cr})$, manganese $(\mathrm{Mn})$, nickel $(\mathrm{Ni})$ and iron $(\mathrm{Fe})$ ]; macronutrients [nitrogen $(\mathrm{N})$ as nitrate, phosphorous $(\mathrm{P})$ as phosphate and potassium $(\mathrm{K})$ ] and environmental characteristics [microbes; faecal coliforms (FC) and total coliforms (TC), biochemical oxygen demand (BOD), chemical oxygen demand (COD), total solid (TS), $\mathrm{pH}$ and chlorides]. Raw data were analysed with the help of Statistical Package for Social Sciences [SPSS] software version 20 for both descriptive statistics (means and standard deviations) and inferential statistics (ANOVA's F and post hoc procedures by Tukey and Games-Howell test where applicable \& Kruskal-Wallis H test. All inferential statistical tests were conducted at a 0.05 level of significance. Results showed that the content of $\mathrm{Cd}, \mathrm{Cr}, \mathrm{Fe}, \mathrm{Mn}$, phosphate, TS, chlorides, and $\mathrm{pH}$ were lower than their safe limits for reuse but that of lead, BOD, COD, nitrates and TC exceeded the recommended threshold limits. Results of one-way ANOVA performed on the data suggested that the levels of all the measured parameters of the study except $\mathrm{Fe}, \mathrm{Pb}, \mathrm{pH}, \mathrm{BOD}$ and $\mathrm{FC}$ varied significantly among the three sites. Overall, the results show that the TWW is not entirely safe for use in its current quality state. There is need for an improved optimal wastewater treatment configuration at DESTW aimed at rendering suitable effluent for reuse schemes in Ruai.
\end{abstract}

Key Terms: treated wastewater, quality, water resource, livelihoods, reuse

DOI: $10.7176 / \mathrm{JEES} / 10-7-07$

Publication date:July $31^{\text {st }} 2020$

\section{Introduction}

1.1 Background

Nairobi City Water and Sewerage Company (NCWSC) operate several wastewater treatment plants with Dandora Estate Sewage Treatment Works (DESTW) in Ruai being the largest and the second biggest in Africa. It processes approximately $80,0000 \mathrm{~m}^{3} /$ day equivalent to about $80 \%$ of wastewater generated in Nairobi city - using the wastewater stabilization ponds (WSP) system (Mireri et al., (2007).

According to Mara, (2001) and Van der Hoek et al., (2002) the WSP system is one of the alternative lowercost treatment technologies used extensively in mid-income countries. It can produce an effluent quality that meets the World Health Organization's (WHO) recommendations for wastewater reuse for crop irrigation (Mara, 2001; Carr and Potter, 2013). Thus, the treated wastewater from WSP should be considered as a valuable resource for reuse by water resources managers (Almas and Scholz, 2006). Besides, wastewater reuse stimulates the treatment efficiency of wastewater which results in the decreasing of pollutants emission into natural environments (Lyu, Chen, Zhang, Fan, Jiao, 2016).

According to Bischel et al. (2012) and Water and Sanitation Program and International Water Management Institute [WSP and IWMI], (2016) municipal wastewater that has been treated thoroughly can be returned to the water supply for a variety of beneficial uses including landscape irrigation, agriculture, ecosystem enhancement, industrial cooling and processing, groundwater recharge, and indirect potable reuse. For instance, TWW has been considered as a viable source of water for several decades in several developed countries in Europe, USA, Japan, and others (Shomar and Dare 2015). Shomar and Dare 2015 further noted that suitable uses of TWW are generally defined at a national level and are often based more on the preference and sensibility of decision makers than scientific evidence about its risks and benefits.

However, in the Ruai case, despite operating on a WSP system, DESTW discharges its effluent into Nairobi 
River (NCWSC, 2015) without any reuse option, the cost of the entire treatment process, and potential reuse options notwithstanding, thus treating it as a 'waste' rather than a resource. Nevertheless, some people among the communities in Ruai use the effluent directly or indirectly in unsustainable (unplanned and unregulated) ways for their livelihoods oblivious of its quality status, putting at risk their own health, public health and the environment. The quality of the TWW released by Ruai's DESTW needed to be documented with respect to its adaptability for safe use and at the same time verified for compliance to the standards for its safe use as recommended by National Environmental Management Authority (NEMA).

\subsection{Objective of the Study}

The specific objective of the study was to establish the current status in quality of TWW - in terms of the concentration levels of heavy metals [lead $(\mathrm{Pb})$, zinc $(\mathrm{Zn})$, copper $(\mathrm{Cu})$, cadmium $(\mathrm{Cd})$, chromium $(\mathrm{Cr})$, manganese $(\mathrm{Mn})$, nickel $(\mathrm{Ni})$ and iron $(\mathrm{Fe})]$; macronutrients [nitrogen $(\mathrm{N})$ as nitrate, phosphorous $(\mathrm{P})$ as phosphate and potassium $(\mathrm{K})$ ] and environmental characteristics [microbes; faecal coliforms (FC) and total coliforms (TC), biochemical oxygen demand (BOD), chemical oxygen demand (COD), total solid (TS), $\mathrm{pH}$ and chlorides] discharged at the three outlets at DESTW.

To help achieve this objective the study sought to answer the following questions:

I. What is the mean concentration of each of the study parameters in the treated wastewater at DESTW?

II. Do these levels conform to the national (NEMA) standards recommended for safe use of the TWW in Ruai? III. Do these concentrations vary significantly among the three outlets of TWW at DESTW? Given the objective of the study, the following hypothesis is spelt out:

$H_{o}$ : There are no significant variations in the concentration of the heavy metal, nutrients and environmental in the TWW discharged among the three outlets at DESTW.

\subsection{Treated Wastewater Quality}

Water resource quality defines subsequent uses and inherent risks (Mahjoub et al. 2016). Thus, the quality of treated wastewater is important, not only for compliance with the regulations to protect farmers irrigating with effluent and consumers of the crops, but also to protect local inhabitants and other users of the resource from incidental contact as noted in Rageh (2014). The types of crops, livestock, and fish that farmers can raise are affected by the quality of the wastewater and the characteristic of the environment (Buechler 2004). It is therefore recommended that the quantity and quality be analysed against potential reuse applications and quality requirements in order to guarantee acceptability by end-users, on the one hand, and to mitigate the risks to practitioners and the environment on the other hand (Mahjoub et al., 2016).

Parameters considered for assessing wastewater quality and selected based on their importance in wastewater treatment and reuse such as in irrigation agriculture included nutrients (Nitrogen [N], Phosphorous [P] and potassium[K), cations and anions (Chlorides and potassium among others), trace elements (iron [Fe], manganese $[\mathrm{Mn}]$, copper $[\mathrm{Cu}]$, zinc $[\mathrm{Zn}]$, cadmium [Cd], lead [Pb],nickel [ $\mathrm{Ni}]$, cobalt $[\mathrm{Co}]$ and chromium $[\mathrm{Cr}]$ ), and acidity / alkalinity (pH) as described in Alghobar and Suresha (2016). For wastewater, parameters such as BOD and COD are paramount as they indicate the efficiency of the treatment process appropriated. Parameters such as $\mathrm{pH}$ can help understand the operating conditions of the system (Kihila et al., 2014). $\mathrm{pH}$ is an indicator of the acidity or basicity of water but is seldom a problem by itself. The normal $\mathrm{pH}$ range for irrigation water is from 6.5 to $8.4 ; \mathrm{pH}$ values outside this range are a good warning that the water is abnormal in quality (Pescod 1992). In hot climates with a long dry season, high rates of evaporation causes wastewater to be more saline with high total dissolved solids (TDS) concentration that may restrict the variety of crops that can be cultivated (Buechler 2004).

Wastewater, particularly from municipal sources, may contain constituents of potential concern including heavy metals (Laurenson et al. 2012), some amount of dissolved mineral salts (Martinez and Clark 2015), nitrogen and phosphorus present as inorganic ammonium, nitrate, and phosphate ions with a smaller proportion of organic forms (Martinez et al., 2015; Ashraf et al., 2017) and soil amendments (Lenntech 2009).

The term heavy metal refers to metals with a density greater than $5 \mathrm{~g} / \mathrm{cm}^{3}$ (Pfleiderer et al., 2012; Mathenge 2013) but the collective term now includes arsenic, cadmium, copper, chromium, lead, nickel, molybdenum, vanadium and zinc. Some interest also exists in aluminium, cobalt, strontium and other rare metals (Njagi 2013). Wastewater may contain various heavy metals including zinc, copper, lead, magnesium, nickel, chromium, and cadmium, depending on its sources of generation (Bhatia, et al., 2015). These metals may make wastewater unsuitable for irrigation (Hussain et al., 2002; Raja et al., 2015) though some are essential elements for growth and development, for example Zinc, Manganese, Copper and iron (Skudi as cited in Karanja 2015). Metals like copper and zinc are essential for enzymatic activity and many biological processes at low concentrations but may become toxic at higher concentrations (Bhatia, et al., 2015). According to USEPA, 2012 as cited in Amare et al., (2017), nickel, cadmium and lead have no known essential functions or role in the body of living organisms but may be toxic even at low concentrations causing a potential health risk through the food chain. Hence, as Amare et al., (2017) further reported, knowledge about these heavy metals' and their concentration in water for use is important, 
more so because they can become a health risk via consumption of contaminated vegetables, milk, fruit, and drinking water. Fortunately or unfortunately, they are typically not removed from wastewater even after treatment, causing risk of heavy metal contamination of wastewater-irrigated soils and, subsequently, can end up in the food chain (Bhatia, et al., 2015).

Wastewater also contains valuable nutrients such as nitrogen, phosphorus and potassium among others which aid in crop growth and could reduce the need for synthetic fertilizers (Kaluli et al., 2011; WSP and IWMI 2016). Nutrients are resources that can beneficially be used by farmers and should not be removed except, during the offseason or whenever nutrients are in excess, where periodic nutrient removal could be a strategy in the treatment system. Nutrients present in the water are beneficial for crop development and depending on the crops grown, the available nutrients are sufficient for crop cultivation, reducing farmer's expenditure on artificial. Balancing nutrients in the field to support crop requirements, while avoiding environmental pollution, gives important incentives to reconsider the wastewater treatment techniques used, as well as the irrigation water management system (Van der Hoek et al., 2002; Van Lier and Hubers 2010; Saldías et al., 2017).

While nitrates are an important source of nitrogen necessary for plants and animals to synthesize amino acids and proteins excessive concentrations of nitrate-nitrogen or nitrite-nitrogen in drinking water can be hazardous to health, especially for infants and pregnant women (Panchagnula 2016) and in wastewater it can lead to overfertilization and cause excessive vegetative growth, delayed or uneven crop maturity and reduced quality (Van der Hoek et al., 2002; Jiménez 2006 and Qadir et al., 2007 as cited in Oyebode 2015).

The phosphate in the reclaimed water is of particular benefit as it has the potential to meet a substantial proportion of crop requirements depending on the crops grown and the intensity of cropping and also essential for animals (Hack, 1992; Carr et al. 2010). However, too much of it in water can contribute to eutrophication (Hack 1992).

In addition to nutrients, the application of wastewater provides organic matter that acts as a soil conditioner, thereby increasing the capacity of the soil to store water (Hespanhol 1997). The increase in productivity is not the only benefit because more land can be irrigated, with the possibility of multiple planting seasons (Hespanhol 1997).

Wastewater use especially untreated or partially treated can also be a source of microbial risk which arises due to pathogens, i.e. disease-causing organisms. Their presence in water/wastewater may be indicated by the presence of non-pathogenic bacteris such as coliforms. According to Bartram and Pedley, (1996), total coliforms refer is a large group of gram-negative, rod-shaped bacteria that share several characteristics. It includes thermotolerant coliforms and bacteria of faecal origin, as well as some bacteria that may be isolated from environmental sources. Their presence in water is evidence of faecal contamination and, therefore, of risk that pathogens are present. The presence of total coliforms may or may not indicate faecal contamination. In extreme cases, a high count for the total coliform group may be associated with a low, or even zero, count for thermotolerant (faecal) coliforms. Such a result would not necessarily indicate the presence of faecal contamination. It might be caused by the entry of soil or organic matter into the water or by conditions suitable for the growth of other types of coliform. Hence, the most appropriate wastewater treatment to be applied before effluent is used in agriculture is one which will produce an effluent meeting the recommended microbiological and chemical quality guidelines (Sewe et al., 2013).

\section{Methodology}

This study was carried out in Ruai sub-location Embakasi Sub County in Nairobi East; about 20 km from the city centre (Figure 1). It lies between latitudes $1^{0} 14^{\prime} 0^{\prime \prime} \mathrm{S}$ and $1^{0} 18^{\prime} 0^{\prime \prime} \mathrm{S}$ and longitudes $36^{0} 56^{\prime} 0^{\prime \prime} \mathrm{E}$ and $37^{0} 6^{\prime} 0^{\prime \prime} \mathrm{E}$. It borders the following sub-counties: Thika to the north, Kangundo to the East, and Kathiani to south. Ruai is connected to City Centre through Kangundo, Outering and Jogoo roads (Sigoria 2012). 


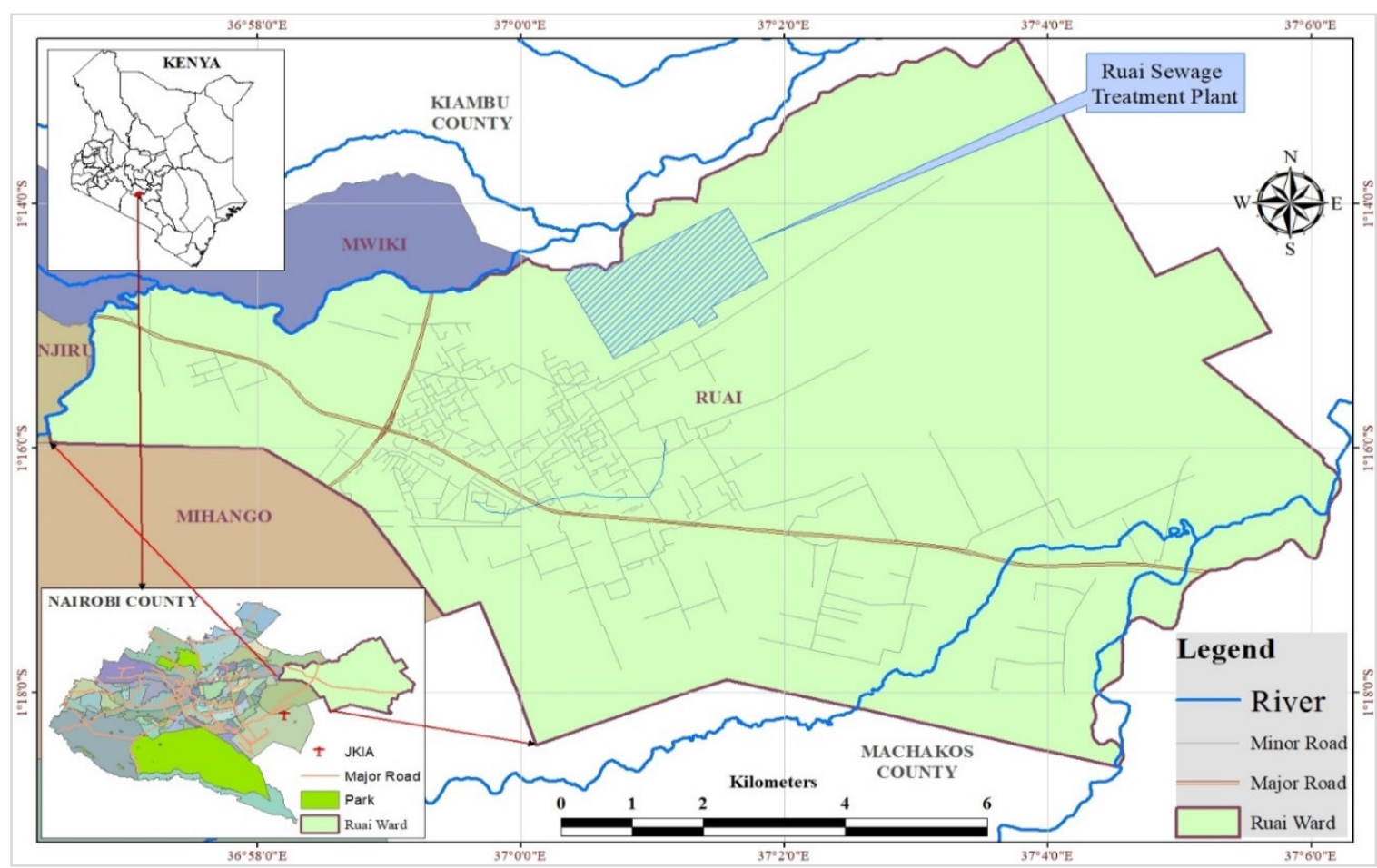

Figure 1: Map of the Study Area

Source: Author

\subsection{Research Design}

The study involved an analytical design where physicochemical data on the status in the quality of the treatment of wastewater were collected, prepared and analysed in accredited science laboratories (Njagi 2013).

\subsection{Treated Wastewater Sampling, Preparation and Analyses}

2.2.1 TWW Samples Collection

Samples of the TWW discharged at DESTW were collected from the three outlets coded in the study as sites A, B and C (Figure 2). This was done thrice - consistent with a similar study in (Raschid-Sally et al., 2004) - during the study period (between February and April, 2019) to reduce errors in sampling processes and to establish any changes in the status of the TWW at different times.

Grab method was used to collect samples of the TWW as recommended by Pitt (2007) and as used in a similar study by Sewe et al., (2013) from the three discharge points. A grabbing plastic bottle was used to collect samples which were then transferred into one litre conical flasks. According to Koffi et al., (2014) water sample for assessing water quality is collected in plastic bottles. Prior to use, the grabbing plastic bottle and the conical flasks were cleaned by pre-soaking them overnight with $10 \%$ nitric acid and rinsed with distilled water as described in Nzeve (2015). The samples were collected manually in the middle and mid-depth of the channels as recommended (Koffi et al. (2014). Three samples were collected, and transferred into three separate conical flasks. The three samples from the conical flasks were then homogenized to form one litre composite treatment sample (Njagi, 2013). The flasks with the composite samples were then labelled to indicate sample number, date of sampling and the sampling site and put in an cooler box at a temperatures of at least $4^{0} \mathrm{C}$ (Nzeve 2015).

The samples were then transported to the DESTW laboratories and University of Nairobi's (UoN) chemistry and biological laboratories where they were stored at $4^{0} \mathrm{C}$ awaiting subsequent laboratory analysis as stipulated in El Moussaoui et al., (2017). 


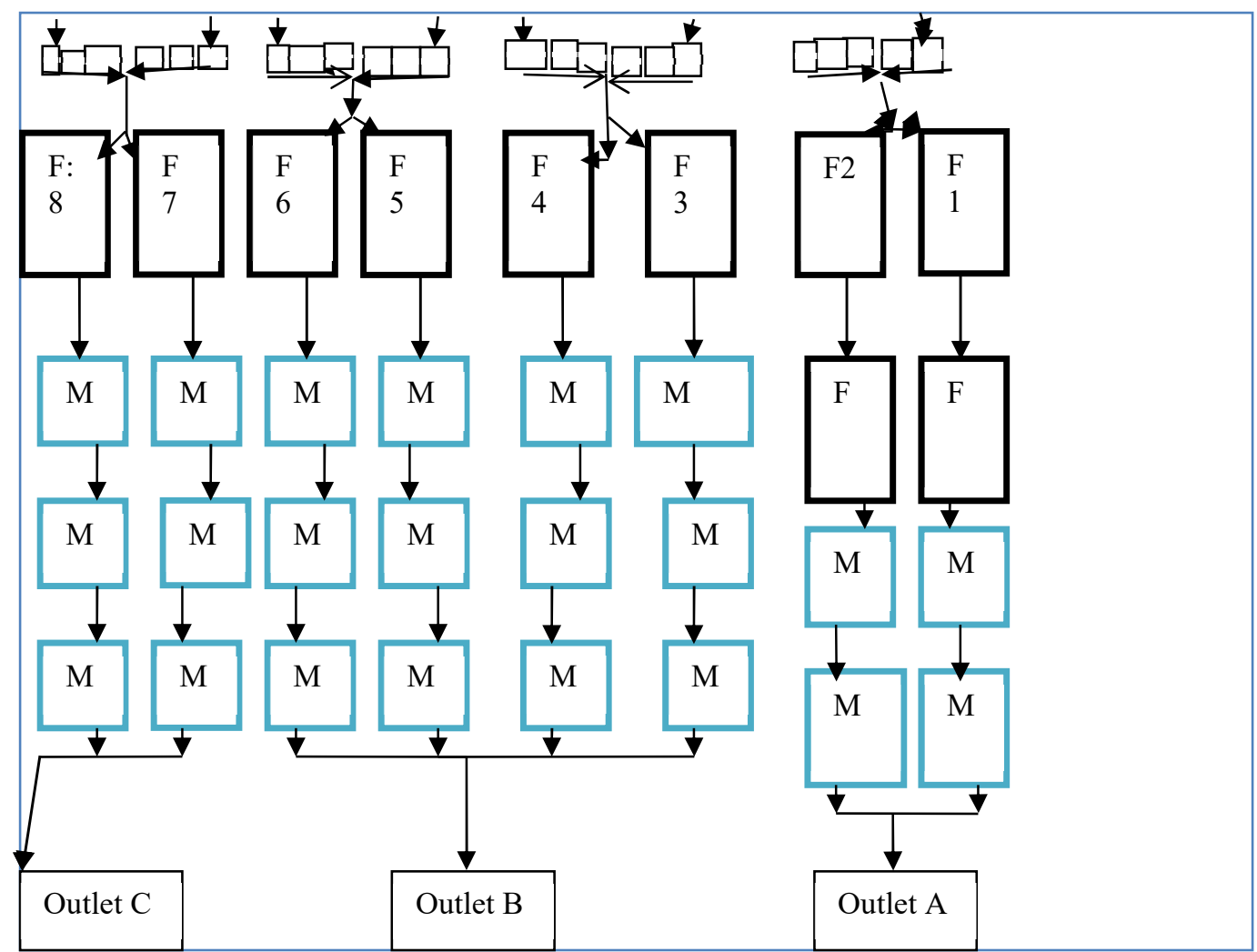

Figure 2: Schematic layout of DESTW Stabilization Ponds and the Outlets

$\mathrm{F}=$ facultative ponds, $\mathrm{M}=$ maturation ponds,

Source [DESTW, Secondary information, February 20, 2019]

\subsubsection{Laboratory Preparations: Standard and Working Solutions}

Stock standards solution of 1000 parts per million (ppm) - [1ppm is equivalent to $1 \mathrm{mg} / \mathrm{l}]$ - for each of the heavy metals were prepared from the metal salts (Analytical grades) using nitric acid as described in Hack (1992) and Nzeve (2015). This was followed by the preparation of the corresponding working standards solutions, ranging from $0.05 \mathrm{ppm}$ to $20 \mathrm{ppm}$ as each case required from the stock solutions by appropriate serial dilutions with distilled water (Hack 1992). Blank solutions (de-ionized water) were also prepared.

2.2.3 Laboratory Analyses

TWW samples were analysed for 18 parameters which were selected based on their importance in wastewater treatment and reuse for irrigation as was done in a similar study (Kihila et al., 2014). They included 8 heavy metals [lead $(\mathrm{Pb})$, zinc $(\mathrm{Zn})$, copper $(\mathrm{Cu})$, cadmium $(\mathrm{Cd})$, chromium $(\mathrm{Cr})$, manganese $(\mathrm{Mn})$, nickel $(\mathrm{Ni})$ and iron $(\mathrm{Fe})]$; three macronutrients [nitrates as nitrogen $(\mathrm{N})$, phosphate as phosphorous $(\mathrm{P})$ and potassium $(\mathrm{K})$ ] and 7 environmental characteristics [microbes; faecal coliforms (FC) and total coliforms (TC), BOD, COD, TS, pH and chlorides]. UoN's chemistry and biological laboratories analysed metals, nutrients and microbes while DESTW laboratories performed the remaining environmental parameters.

Laboratory analyses for estimating the concentration of the metals in the TWW were carried out using atomic absorption spectrometer (AAS) using the respective hallow cathode lamp (Hack 1992; Eaton et al. 2005; Koffi et al. 2014; Amare et al. 2017; El Moussaoui et al., 2017). To determine the instrument signal response to changes in concentration, calibration was done using working standard solutions of known and increasing concentrations for each metal (analyte element) in the study as stipulated in Hack (1992) and Amare et al., (2017). By measuring the signals of the working standards, the AAS constructed a suitable calibration curve of response/absorbance versus concentration. The AAS used this suitable graph to determine concentrations of unknown analyte as described in Hack (1992); Nzeve (2015) and Skudi, as cited in Mathenge (2013). Analytical samples, blanks and duplicate samples were run in parallel for each analysis. All the samples were analysed in triplicate.

Nutrients were analysed using a visible/ultra violet (UV) spectrophotometer (calorimeter) as described in Hack (1992). The samples for determining nitrate levels were first digested with conc. sulphuric acid, a catalyst and distilled water. A Nessler's reagent was added in every analysis and the mixture run in a UV spectrophotometer at an absorbance of $425 \mathrm{~nm}$. Procedure for determining the levels of phosphate in the sample involved 1). Stock solution (100ppm) was prepared and then diluted to obtain working standards of $10 \mathrm{ppm}, 20 \mathrm{ppm}$... up to $90 \mathrm{ppm}$. $1 \mathrm{~cm}^{3}$ reagent (molybdovanadate) was then added to each standard. 2) Preparation of samples where $1 \mathrm{ml}$ of the reagent was added to $10 \mathrm{mls}$ of the each sample and 3) running the standards, samples and blank solutions in a 
UV/visible spectrophotometer (calorimeter) at a wavelength of 470nm (Hach 1992). Potassium levels in the sample were determined following the same methods used for the analysis of heavy metals.

Biochemical oxygen demand (BOD) was determined using a 5-day digital BOD test at $20{ }^{\circ} \mathrm{C}$ as described in Eaton et al. (2005) and Amare et al., (2017). For Chemical oxygen demand (COD) determination, the sample was mixed with $1.5 \mathrm{ml}$ potassium dichromate solution and $3.5 \mathrm{ml}$ sulphuric acid (catalyst) in a Rota mixer digester for two hours. The mixture was allowed to cool and then titrated with phenolphthalein indicator (Eaton et al., 2005). A standard solution (distilled water) was used. Chlorides levels were determined by titration method with silver nitrate solution and acidified potassium dichromate solution as the indicator. A standard of sodium chloride solution was used. Conversion of units of measurement of chloride determined from $\mathrm{ml}$ to $\mathrm{mg} / \mathrm{l}$ was done as follows: $\frac{m g}{l}$ chloride $=\frac{(A-B) * \text { Normality of AgN03 sample } * \text { constant }}{\text { ml of sample }}$

Where: $\mathrm{A}=$ sample titre, $\mathrm{B}=$ blank titre and constant $=35450$.

The $\mathrm{pH}$ of the wastewater was measured using a portable $\mathrm{pH}$ meter. Total solids (TS) were analysed as follows: metallic crucibles were dried at $150^{\circ}$ overnight, and then cooled in a desiccator and each weighed $\left(\mathrm{W}_{1}\right) .50 \mathrm{mls}$ of TWW sample was put into an empty dry metallic crucible and dried for 12 hours, cooled and weighed $\left(\mathrm{W}_{2}\right)(\mathrm{Eaton}$ et al. 2005; Koffi et al. 2014). The procedure was done in triplicate. TS (mg/l) were calculated according to Aminot and Chaussepied as cited in Koffi et al., (2014) as follows:

$\mathrm{TS}=\left[\left(\mathrm{W}_{2}-\mathrm{W}_{1}\right) * 1000\right] /$ sample volume $(\mathrm{ml})$.

Bacteriological laboratory analyses were undertaken following the plate count method (Hack, 1992). Two growth media were used namely Eosin methylene blue agar for indication of faecal coliform (FC) and MacConkey agar for enumeration of total coliform (TC) as recommended in Hack (1992). $1 \mathrm{ml}$ of each sample (A, B and C) was serial diluted up to $10^{5}$. Then $0.1 \mathrm{ml}$ of the last 3 dilutions was transferred on to the growth media and using a sterile spread rod they were spread uniformly. The plates were then incubated at $37^{\circ} \mathrm{c}$ for 48 hours and the colonies that developed were enumerated. For the TC all the plates which had more than 300 colonies were discarded.

\subsection{Statistical Data Analysis}

Data from laboratory analyses were statistically analysed using both the Ms Excel and the SPSS (Version 20.0) software. Descriptive analyses (that is, mean and standard deviations) were done and presented in tables. The mean level of concentration of each parameter in the study was also compared with the set standards by NEMA and WHO or Food and Agriculture Organization (FAO) where available in order to ascertain safe use of TWW. At the same time, the resultant concentration levels for the parameters of TWW were subjected to a one-way analysis of variance (ANOVA) followed by Tukey HSD or Games-Howell multiple comparison tests where applicable. The resulting $F$ statistic and its corresponding significant level $(p)$ in each case were used to determine the significance of the differences of their mean levels, both within the site and between the sampling sites in the study. The means were deemed significantly different when $p \leq 0.05$ and insignificant when $p>0.05$ at $95 \%$ confidence interval.

A one-way ANOVA is a hypothesis test that determines whether there are any significant differences among the means of three or more independent (unrelated) populations or categories (Shayib 2013). The independent groups (categorical) in the study were the three sampling sites whereas the dependent variable at scale level as stipulated in Norušis (2008) and Nolan and Heinzen (2011) was the mean level of each of the treated wastewater parameters analysed. The null hypothesis tested in the study was that the population values for mean levels of each of the TWW parameters were the same for the three sites of wastewater at DESTW (Norušis, 2008).

According to Shayib (2013) and Norušis, (2008), the methodology of ANOVA is based on the following assumptions: (1) each sample of size $n$ is drawn randomly and is therefore independent of the other samples, (2) the populations are normally distributed as ANOVA is a relatively robust procedure for violations of the normality assumption (Shayib, 2013), (3) the populations from which the samples are drawn have equal variances. This means that:

$$
\sigma_{1}^{2}=\sigma_{2}^{2}=\cdots=\sigma_{k}^{2} \text { for } k \text { populations. }
$$

Where $\sigma^{2}$ is the variance of populations $1,2 \ldots$ to $\mathrm{k}$

The ANOVA produces an F statistic, the ratio of the variance among the means to the variance within the samples (Shayib, 2013; Norušis, (2008) :

$$
F=\frac{\text { Mean squared for between - group variation }}{\text { Mean squared for within - group variation. }}
$$

The following procedures were followed in conducting the one-way ANOVA): (1) Cleaning the data, (2) Checking and testing the assumptions of one-way ANOVA. The study used the Shapiro Wilk test for testing normality as it is more appropriate for small sample sizes, more powerful than the K-S test even after the Lilliefors correction, has good power properties as compared to a wide range of alternative tests and is also an omnibus test in most situations (Öztuna et al., 2006; Razali and Wah 2011; Ghasemi and Zahediasl 2012). For numerical 
variables with skewed distributions, the Kruskal-Wallis rank sum test was then used as described in (Ghasemi and Zahediasl, (2012) and Salkind, 2007). It is the non-parametric analogue of a one-way ANOVA (McDonald 2014). In practice, the analysis of variance is not heavily dependent on the normality assumption (Norušis, 2008).

Levene test statistic was used for homogeneity testing (Norušis, 2008; Ghasemi and Zahediasl 2012). (3)

Calculating the respective $\mathrm{F}$ ratio and its associated significant probability $(p)$ value and (4) Conducting post hoc procedures using the Tukey HSD and Games-Howell tests for equal variances assumed and not assumed respectively where a significant difference $(p \leq 0.05)$ had been found in the preceding ANOVA analysis (Salkind, 2007). Tukey HSD which assumes homogeneity works for any number of groups with roughly equal sample sizes whereas Games-Howell is a separate variance version of Tukey test (Elder, 2009). Following Kruskal-Wallis rank tests, pairwise comparisons tests were done to ascertain where any significant differences in distributions occurred.

\section{Results and Discussion}

The statistical results of the study are presented systematically as follows: Descriptive statistics comprising the means and standard deviations of the concentration levels of the parameters of the TWW sampled. Inferential statistics follows; starting with the results of tests of the assumptions of the one-way ANOVA (normality of the raw data and homogeneity of variances) and then the results of one-way ANOVA and post hoc procedures. Results of Kruskal-Wallis rank-sum test for the skewed data closes the section.

\subsection{Descriptive analyses of qualitative status of TWW}

Table 1 shows the mean levels of the parameters studied in each site, their overall average and comparisons with NEMA and international recommended standards (where applicable) for safe use, as discussed below.

3.1.1 Environmental Parameters

The means of most of the environmental parameters in the study $[\mathrm{pH}, \mathrm{TS}, \mathrm{BOD}, \mathrm{COD}$, Chlorides and microbes; FC and TC), were similar in the three sites except a slight difference which was noted among the mean levels of BOD and FC. For instance, mean level of BOD of TWW from site B was $106.71 \mathrm{mg} / 1$ compared to both C of $71.43 \mathrm{mg} / \mathrm{l}$ and site $\mathrm{A}$ at $62.1 \mathrm{mg} / \mathrm{l}$. The mean counts of $\mathrm{FC}$ in all the three outlets differed.

The results further show both compliance and non-compliance with the standards among the parameters. Among the parameters that complied with the NEMA recommended standards (given in brackets) for safe use includes, TS $[888.0 \mathrm{mg} / \mathrm{l}(1230 \mathrm{mg} / \mathrm{l})]$, chlorides $[137.0 \mathrm{mg} / \mathrm{l}(250) \mathrm{mg} / \mathrm{l}]$, and $\mathrm{pH}$ [8.3 (6.5-8.5)] while BOD [80 $\mathrm{mg} / \mathrm{l}(30 \mathrm{mg} / \mathrm{l})]$, and COD [278.0 $\mathrm{mg} / \mathrm{l}(50 \mathrm{mg} / \mathrm{l})]$ were above the recommended standards. The results for the BOD and COD were consistent with finding of a study by Sewe et al., (2013) on the efficiency of DESTW which reported that the BOD-5 and COD in the final effluents failed to meet not only the design expectation but also the required water quality regulations of Kenya for discharge to the surface water and environment. This is an indication of inefficiency of the treatment process appropriated (Kihila et al., 2014) for a while now. One reason for this is the fact that the ponds have not been de-sludged since construction as noted in a previous study by Sewe et al., (2013). The average mean colonies of TC $\left[2.1 \times 10^{5}(1000\right.$ colonies per $\left.100 \mathrm{mls})\right]$ were above the recommended standards. This poses a health risk to the users of TWW in Ruai and consumers of agricultural produce resulting from its use.

3.1.2 Heavy Metals

The mean concentration levels of each of the heavy metals studied were relatively similar in the three sites except those of iron $(\mathrm{Fe})$ and lead $(\mathrm{Pb})$. Further, except for lead $[0.158 \mathrm{mg} / 1]$, the levels were below the NEMA'S standards $(0.1 \mathrm{mg} / \mathrm{l})$ for safe use. In this regard, the TWW from DESTW in Ruai was safe for use in relation to the heavy metals in the study except lead.

3.1.3 Nutrients

While the mean levels of potassium and phosphate were relatively similar in the three sites, there was a large variation in the mean of nitrate in site C $(50.8 \mathrm{mg} / \mathrm{l})$ from the other two (around $38 \mathrm{mg} / \mathrm{l})$. The mean levels of phosphate $(3.0 \mathrm{mg} / \mathrm{l})$ complied with the NEMA recommended standards $(30 \mathrm{mg} / \mathrm{l})$ for safe use while those of nitrate $(42 \mathrm{mg} / \mathrm{l})$ exceeded the threshold limit $(10 \mathrm{mg} / \mathrm{l})$. These findings are similar to those in a study by van der Hoek et al., (2002) who found that the level of nitrogen in the wastewater was too high and therefore could lead to excessive vegetative growth. 
Table 1: Mean Concentration Levels of Parameters of TWW in Comparison with Recommended Standards

\begin{tabular}{|c|c|c|c|c|c|c|}
\hline Parameter & $\begin{array}{l}\text { Site A mean } \\
\text { levels } \pm \mathrm{SD} \\
\quad(\mathrm{mg} / \mathrm{l})\end{array}$ & $\begin{array}{l}\text { Site B mean } \\
\text { levels } \pm \mathrm{SD} \\
\quad(\mathrm{mg} / \mathrm{l})\end{array}$ & $\begin{array}{l}\text { Site C mean } \\
\text { levels } \pm \mathrm{SD} \\
(\mathrm{mg} / \mathrm{l})\end{array}$ & $\begin{array}{c}\text { Average } \\
\text { levels } \pm \text { SD } \\
(\mathrm{mg} / \mathrm{l})\end{array}$ & $\begin{array}{c}\text { NEMA } \\
(\mathrm{mg} / \mathrm{l})\end{array}$ & $\begin{array}{c}\text { WHO* / } \\
\text { FAO** } \\
\text { Standards } \\
\text { (mg/l) }\end{array}$ \\
\hline $\mathrm{Cd}$ & $0.054 \pm .007$ & $0.058 \pm .009$ & $0.063 \pm .013$ & $0.058 \pm .010$ & 0.1 & $0.01 * *$ \\
\hline $\mathrm{Cr}$ & $0.091 \pm .068$ & $0.104 \pm .023$ & $0.089 \pm .032$ & $0.094 \pm .047$ & 2.0 & $0.1 * *$ \\
\hline $\mathrm{Cu}$ & $0.056 \pm .012$ & $0.061 \pm .005$ & $0.058 \pm .013$ & $0.059 \pm .009$ & 1.0 & $0.2 * *$ \\
\hline $\mathrm{Fe}$ & $0.442 \pm .087$ & $0.272 \pm .072$ & $0.402 \pm .087$ & $0.372 \pm .107$ & 10.0 & $5.0 * *$ \\
\hline $\mathrm{Pb}$ & $0.294 \pm .056$ & $0.196 \pm .028$ & $0.071 \pm .034$ & $0.158 \pm .105$ & 0.1 & $5.0 * *$ \\
\hline $\mathrm{Ni}$ & $0.090 \pm .057$ & $0.095 \pm .073$ & $0.175 \pm .117$ & $0.117 \pm .087$ & 0.3 & $0.2 * *$ \\
\hline Mn & $0.678 \pm .151$ & $0.654 \pm .058$ & $0.754 \pm .014$ & $0.695 \pm .098$ & 10.0 & $0.2 * *$ \\
\hline $\mathrm{Zn}$ & $0.035 \pm .006$ & $0.037 \pm .005$ & $0.051 \pm .026$ & $0.041 \pm .016$ & 0.5 & $2.0 * *$ \\
\hline $\mathrm{K}$ & $1.33 \pm .531$ & $1.448 \pm .68$ & $1.47 \pm .543$ & $1.42 \pm .556$ & N/A & \\
\hline Nitrate & $38.4 \pm 14.8$ & $38.0 \pm 12.9$ & $50.8 \pm 27.5$ & $42.4 \pm 18.8$ & 10.0 & \\
\hline Phosphate & $3.14 \pm 0.9$ & $3.15 \pm 0.35$ & $2.74 \pm .19$ & $2.98 \pm .59$ & 30.0 & \\
\hline Chlorides & $132.8 \pm 13.5$ & $139.6 \pm 4.3$ & $138.3 \pm 9.8$ & $136.9 \pm 9.9$ & 250 & \\
\hline $\mathrm{pH}^{\mathrm{a}}$ & $8.6 \pm .25$ & $8.2 \pm .10$ & $8.1 \pm .08$ & $8.3 \pm .25$ & $6.5-8.5$ & $6.5-8 * *$ \\
\hline $\mathrm{TS}$ & $858.9 \pm 72.1$ & $899.6 \pm 29.8$ & $905.5 \pm 53.0$ & $888.0 \pm 56.2$ & 1230.0 & \\
\hline BOD & $62.1 \pm 16.4$ & $106.7 \pm 46.1$ & $71.4 \pm 11.6$ & $80.1 \pm 33.8$ & 30.0 & \\
\hline COD & $286.0 \pm 60.2$ & $277.3 \pm 28.7$ & $271.4 \pm 27.9$ & $278.2 \pm 40.4$ & 50.0 & \\
\hline $\mathrm{FC}^{\mathrm{b}}$ & $6.0 \pm 6.0$ & $10.0 \pm 3.0$ & $27.0 \pm 7.0$ & $14.0 \pm 11.0$ & Nil. & $\begin{array}{c}1000.0 \\
/ 100 \mathrm{ml}^{* * *}\end{array}$ \\
\hline $\mathrm{TC}^{\mathrm{b}}$ & $\begin{array}{c}218667.0 \pm \\
59651.0\end{array}$ & $\begin{array}{c}210167 \pm \\
60407 \\
\end{array}$ & $\begin{array}{c}211167 \pm \\
41845 \\
\end{array}$ & $\begin{array}{c}213333 \pm \\
51478 \\
\end{array}$ & $\begin{array}{l}1000.0 \\
/ 100 \mathrm{ml}\end{array}$ & \\
\hline
\end{tabular}

Note. ${ }^{\mathrm{a}} \mathrm{pH}$ scale (range $\left.1-14\right),{ }^{\mathrm{b}}$ Levels of coliforms $(\mathrm{FC}=$ faecal coliforms and $\mathrm{TC}=$ total coliforms) are measured in counts per 100 milliliter. N/A = Not available, *source: Mara, (2001), **source: Adapted from Pescod, (1992), $* * *$ No standards recommended for cereal and fodder crops, pasture and trees but $\leq 1000 / 100 \mathrm{ml}$ for irrigation of crops likely to be eaten uncooked and public parks.

\subsection{Inferential Statistical Analysis}

3.2.1 Results of Normality Test

Results of the Shapiro-Wilk normality tests for levels of Cd, Fe, Ni, Zn, TS, pH, COD and nitrate (in all the three sites) had their $p$-values greater than 0.05 (Appendix A, Table A.1). This indicated absence of sufficient evidence to reject the null hypothesis for a test of normality which states that the data is normally distributed. Hence, the assumption of normality was not violated. Consequently, these data were subjected to one-way ANOVA test as explained below. However, the data for $\mathrm{Cr}$ (site B), $\mathrm{Cu}$ (site C), Mn (sites A and B), Pb (site C), K (sites B and C), Chlorides (site B), BOD (site B), Phosphate (site A), FC (site A) and TC (site B) were not normally distributed as their $p$-values were less than 0.05 . Hence, we rejected the null hypothesis for this test of normality necessitating the use of the Kruskal-Wallis rank-sum test to separate their differences as described in Ghasemi and Zahediasl, (2012) and Salkind, (2007).

3.2.2 Results of Homogeneity Test

As Table 2 shows, the results from Levene tests for homogeneity of variances indicated that the null hypothesis which states that the variances in the three discharge sites of TWW were equal could not be rejected for $\mathrm{Cu}, \mathrm{Fe}$, $\mathrm{Pb}, \mathrm{TS}, \mathrm{COD}$ and TC. However, the tests showed statistical significance $(p \leq 0.05)$ for the variances of the groups for $\mathrm{Cd}, \mathrm{Cr}, \mathrm{Ni}, \mathrm{Mn}, \mathrm{Zn}, \mathrm{K}, \mathrm{BOD}, \mathrm{pH}$, Chlorides, Nitrates, Phosphates and Faecal coliforms. Hence, the null hypothesis was not accepted. So, where necessary, it was reasonable to use post hoc procedures that assume and don't assume equality of group variances (Norušis 2008). 
Table 2: Results for the Levene Test of Homogeneity of Variances

\begin{tabular}{cccccccccc}
\hline Parameter & Levene Statistic & df1 & df2 & Sig. & Parameter & Levene Statistic & df1 & df2 & Sig. \\
\hline $\mathrm{Cd}$ & 6.287 & 2 & 15 & .010 & Nitrate & 74.383 & 2 & 9 & .000 \\
$\mathrm{Cr}$ & 6.023 & 2 & 8 & .025 & Phosphate & 27.983 & 2 & 15 & .000 \\
$\mathrm{Cu}$ & 2.147 & 2 & 6 & .198 & FC & 7.524 & 2 & 15 & .005 \\
$\mathrm{Fe}$ & 0.097 & 2 & 15 & .909 & $\mathrm{TC}$ & 1.705 & 2 & 15 & .215 \\
$\mathrm{~Pb}$ & 1.198 & 2 & 5 & .376 & TS & 2.544 & 2 & 21 & .102 \\
$\mathrm{Ni}$ & 4.737 & 2 & 14 & .027 & Chloride & 5.175 & 2 & 21 & .015 \\
$\mathrm{Mn}$ & 494.70 & 2 & 15 & .000 & $\mathrm{pH}$ & 6.056 & 2 & 21 & .008 \\
$\mathrm{Zn}$ & 3.777 & 2 & 14 & .049 & BOD & 9.63 & 2 & 18 & .001 \\
$\mathrm{~K}$ & 3.749 & 2 & 15 & .048 & COD & 3.065 & 2 & 21 & .068 \\
\hline
\end{tabular}

Note. Significance level used is .05

\subsubsection{Results of One-way ANOVA}

Table 3 shows results of a one-way ANOVA test. It was computed to test the null hypothesis that the population values for mean levels of each of the TWW parameters (whose data were normal as earlier explained) were the same for the three sites of discharge of the treated wastewater at DESTW as described in Norušis (2008). Results showed no statistically significant difference in the levels of Cd, Ni, Zn, TS, COD and nitrates in all the three sites. For these parameters the null hypothesis of the study could not be rejected. However, there was a statistically significant difference in the levels of $\mathrm{Fe}[F(2,15)=7.06]$ and $\mathrm{pH}[F(2,21)=15.98]$ among the three discharge sites of TWW at $p \leq .05$. In this regard it was unlikely that the mean levels of the two parameters in the TWW from the three sites were the same. The null hypothesis was therefore rejected, and based on Levene test results, Tukey HSD procedure was carried out for Fe while Games-Howell procedure was used for $\mathrm{pH}$ in order to pinpoint exactly where the differences occurred.

Table 3: One-way ANOVA of Mean Levels of the Parameter of TWW among the Three Sites at DESTW

\begin{tabular}{cccccccc}
\hline Parameter & df & $\boldsymbol{F}$ & $\boldsymbol{p}$ & Parameter & df & $\boldsymbol{F}$ & $\boldsymbol{p}$ \\
\hline $\mathrm{Cd}$ & $(2,15)$ & 1.105 & 0.357 & $\mathrm{TS}$ & $(2,21)$ & 1.739 & 0.200 \\
$\mathrm{Fe}$ & $(2,15)$ & 7.056 & 0.007 & $\mathrm{pH}$ & $(2,21)$ & 15.979 & 0.000 \\
$\mathrm{Ni}$ & $(2,14)$ & 1.751 & 0.210 & $\mathrm{COD}$ & $(2,21)$ & 0.248 & 0.782 \\
$\mathrm{Zn}$ & $(2,14)$ & 1.922 & 0.183 & Nitrate & $(2,9)$ & 0.557 & 0.591 \\
\hline
\end{tabular}

Note. Statistical significant at the $\mathrm{p} \leq 0.05$ levels

Tukey HSD test results as presented in Table 4, showed a significant mean difference $(p \leq .05)$ for Fe between site $\mathrm{A}(M=.442 \pm .087)$ and $\mathrm{B}(M=.272 \pm .072)$ as well as between site $\mathrm{B}(M=.272 \pm .072)$ and site $\mathrm{C}(M=.402$ $\pm .087)$. However, there were no statistical differences between the site $\mathrm{A}$ and $\mathrm{C}(p=0.685)$. On the other hand, the Games-Howell tests revealed significant mean difference $(p \leq .05)$ for $\mathrm{pH}$ between site $\mathrm{A}(M=8.6, S D=.25)$ and site $\mathrm{B}(M=8.2 \pm .10)$ and between site $\mathrm{A}(M=8.5 \pm .25)$ and site $\mathrm{C}(M=8.1 \pm .08)$. There were no differences between the means for $\mathrm{pH}$ at sites $\mathrm{B}$ and $\mathrm{C}$. This implies that variations exist in the performances of the treatment processes among the corresponding series at DESTW.

Table 4: Output of Multiple Comparisons Tests

\begin{tabular}{|c|c|c|c|c|c|c|c|c|c|}
\hline \multicolumn{5}{|c|}{ Fe Tukey HSD } & \multicolumn{5}{|c|}{ pH Games-Howell } \\
\hline $\begin{array}{l}\text { (I) } \\
\text { site }\end{array}$ & $\begin{array}{l}\text { (J) } \\
\text { site }\end{array}$ & $\begin{array}{l}\text { Mean Difference (I- } \\
\text { J) }\end{array}$ & $\begin{array}{l}\text { Std. } \\
\text { Error }\end{array}$ & Sig. & $\begin{array}{l}\text { (I) } \\
\text { site }\end{array}$ & $\begin{array}{l}(\mathrm{J}) \\
\text { site }\end{array}$ & $\begin{array}{l}\text { Mean Difference (I- } \\
\text { J) }\end{array}$ & $\begin{array}{l}\text { Std. } \\
\text { Error }\end{array}$ & Sig. \\
\hline \multirow{2}{*}{ A } & Site B & $.170^{*}$ & .047 & .007 & \multirow{2}{*}{ A } & site $B$ & $.366^{*}$ & .096 & .010 \\
\hline & Site C & .040 & .047 & .685 & & site $\mathrm{C}$ & $.425^{*}$ & .093 & .004 \\
\hline \multirow{2}{*}{ B } & Site A & $-.170^{*}$ & .047 & .007 & \multirow{2}{*}{ B } & site $\mathrm{A}$ & $-.366^{*}$ & .096 & .010 \\
\hline & Site C & $-.130^{*}$ & .047 & .037 & & site $\mathrm{C}$ & .059 & .046 & .425 \\
\hline \multirow{2}{*}{$\mathrm{C}$} & Site A & -.040 & .047 & .685 & \multirow{2}{*}{$\mathrm{C}$} & site $\mathrm{A}$ & $-.425^{*}$ & .093 & .004 \\
\hline & Site B & $.130^{*}$ & .047 & .037 & & site $B$ & -.059 & .046 & .425 \\
\hline
\end{tabular}

Note. ${ }^{*}$. The mean difference is significant at $p \leq 0.05$

Results of a Kruskal-Wallis test (Table 5) showed that there was no statistically significant difference (with $p>.05)$ in distribution of levels of $\mathrm{Cr}, \mathrm{Cu}, \mathrm{K}, \mathrm{Mn}$, chlorides, phosphates and TC across categories of the sites. So we did not have sufficient evidence to reject the null hypothesis, that the distributions were the same. See details of ranks in Appendix B, Table B.1. This indicates no significant variations in the performances of the treatment processes among the corresponding series at DESTW.

However, the test showed a statistically significant difference $(p \leq 0.05)$ in distribution of levels of $\mathrm{Pb}, \mathrm{BOD}$ and $\mathrm{FC}$ across the categories. Corresponding pairwise comparisons tests shows significant differences (at $p \leq 0.05)$ in the distribution of BOD between site $\mathrm{C}$ and site $\mathrm{B}$, as well as distribution of FC between sites A and Site $\mathrm{C}$ and between site B and site C, (Appendix B, Table B.2). This indicates that the treatment processes for the removal of pathogens and breakdown of organic matter (BOD) differed across the respective series at DESTW (Mara (2001). 
Table 5: Results for Kruskal-Wallis Test

Test Statistics ${ }^{a, b}$

\begin{tabular}{cccccccc}
\hline Parameter & Chi-square & df & $\mathbf{p}$ & Parameter & Chi-square & df & $\mathbf{p}$ \\
\hline $\mathrm{Cr}$ & .247 & 2 & .884 & Phosphate & .649 & 2 & .723 \\
$\mathrm{Cu}$ & .318 & 2 & .853 & Chlorides & 1.512 & 2 & .469 \\
$\mathrm{~Pb}$ & 6.072 & 2 & .048 & BOD & 7.132 & 2 & .028 \\
$\mathrm{Mn}$ & 3.789 & 2 & .150 & FC & 11.986 & 2 & .002 \\
$\mathrm{~K}$ & .573 & 2 & .751 & TC & .266 & 2 & .875 \\
\hline
\end{tabular}

Note. a. Kruskal-Wallis Test, b. Grouping Variable: Site.

\section{Conclusion and Recommendations}

This study revealed that the TWW currently discharged at DESTW contained parameters (all the heavy metals in the study except lead; TS, $\mathrm{Cl}$ and $\mathrm{pH}$ ) that are at a non-harmful degree with respect to NEMA's safety standards for use and unacceptably high loads of BOD, COD, nitrates and both faecal and total coliforms which constitute a great health concern. There was also a remarkable difference in the quality of TWW discharged among the three outlets of TWW at DESTW with respect to parameters such as $\mathrm{Fe}, \mathrm{Pb}, \mathrm{pH}, \mathrm{BOD}$ and $\mathrm{FC}$. This indicates a marked difference in the performance of the treatment processes among the corresponding series at DESTW. With 12 out of 18 parameters tested in the study falling within safety bounds, the overall status in quality of TWW can be said to be about $67 \%$ safe for use. In this regard, the DESTW seems to have great potential for producing TWW that is safe for reuse, however, the current status in quality of the TWW imply a partial inefficiency toward that end. Hence, this marginal water is not entirely safe for reuse in its current state in terms of quality and its usage poses human health and environmental risks which can impact negatively on sustainability of people's livelihoods.

Therefore, there is need for sustained proper care and maintenance of wastewater processes at DESTW's WSP, in order to produce appropriate quality marginal water that meets all the NEMA's recommendations for wastewater reuse in, say, crop irrigation, instead of just being disposed of as noted in Keremane and Mckay (2006). Perhaps also, its time the idea of a constructed wetland (CW) system was actualized at DESTW to supplement the WSP one for better removal of pathogens and nutrients prior to releasing the effluent into water supplies as recommended in Cakmak \& Apaydin, (2010). According to Kihila et al., 2014, with the integration of the treatment technologies and proper operation of the system more better quality effluent can be availed whereby organic load can be reduced significantly and relatively significant amounts of nutrients can be made available for irrigation.

In the meantime, based on the observed effluent quality, restricted irrigation may be employed for growing crops that are eaten when cooked. Crop restriction is one of the health protection measures applied on farms to reduce the risk of contamination for exposed consumers, especially for crops eaten raw (Mahjoub et al., 2016). Both public and environmental health risks associated with TWW reuse in Ruai need to be assessed, managed, monitored and reported on a regular basis in order to sensitize the public on the status of its quality for the purpose of minimizing the negative impacts.

Relevant policies, institutional mandates, and control regulations should be formulated or reviewed, legislated and enhanced to include and ensure that TWW use is part of the integrated management of urban water. This would be in line with an observation made that wastewater is a water resource management and that water quality issue and its reuse is an important option for integrated water resources management in (Bahri, 2009 and Oyebode 2015). Water reclamation and recycling are considered as key components of water and wastewater management policies around the world (Keremane and Mckay 2006).

Conflict of Interest: No potential conflict of interest is reported by the authors.

\section{Acknowledgments}

First and foremost, is to thank the Almighty God for his sufficient grace, favor, good health, financial breakthrough inter alia in every step of this study which forms part of the requirements for the Doctor of Philosophy degree of Pwani University. I also want to acknowledge and thank several people who supported me in this noble task: my supervisors; Dr A. Wamukota and Dr M. Mwakumanya for their guidance and scholarly advice, laboratory technicians at DESTW and University of Nairobi's Chemistry and Biological laboratories for their timely and selfless assistance during the laboratory analyses. Special thanks go to the coordinator and his administration at DESTW for their invaluable support. Finally every other person who played a role in one way or another to make the study a success is also highly appreciated.

\section{References}

Alghobar, M. A and Suresha, S. (2016). Effect of wastewater irrigation on growth and yield of rice crop and uptake and accumulation of nutrient and heavy metals in soil. Applied Ecology and Environmental Sciences, doi: 
10.12691/aees-4-3-1

Almas, A. A. M., and Scholz, M. (2006). Potential for wastewater reuse in irrigation: Case study from Aden (Yemen). International Journal of Environmental Studies, 131-412. doi.org/10.1080/00207230500505569

Amare, E., Kebede, F., Kloos, H., and Mulat, W. (2017). Wastewater confronting realities for sustainable livelihood in developing countries: case study Mekelle University, Ethiopia. Water Conservation Science and Engineering, 2: 21-30. doi.org/10.1007/s41101-017-0021-7

Ashraf, M., Safdar, M.E., Shahzad, S.M., Aziz, A., Piracaha, M.A., Suleman, M. and Ahmad, M.B. (2017). Challenges and opportunities for using wastewater in agriculture: a review. Journal of Applied Agriculture and Biotechnology, 2(2): 1-20.

Bahri, A. (2009). Managing the other side of the water cycle: Making wastewater an asset. Global Water Partnership. Technical Committee. Papers No. 13. Stockholm: Global Water Partnership

Bartram, J. and Pedley, S (1996). Microbiological analysis. In Bartram, J and Ballance, R (Eds) Water quality monitoring - a practical guide to the design and implementation of freshwater quality studies and monitoring programmes. UNEP/WHO. ISBN 0419223207 (Hbk) 0419217304 (Pbk)

Bhatia, A., Singh, S.D. and Kumar, A. (2015). Heavy metal contamination of soil, irrigation water and vegetables in peri-urban agricultural areas and markets of delhi. Water Environment Research. 87 (11): 2027-2034. doi: $0.2175 / 106143015 \times 14362865226833$

Bischel, H., Simon, G., Frisby, T., and Luthy, R. (2012). Management experiences and trends for water reuse implementation in Northern California. Environmental Science and Technology 46:180-188

Buechler, S. (2004). A sustainable livelihoods approach for action research on wastewater use in agriculture In: Scott C, A., Faruqui, N.I., and Raschid-Sally L (Eds), Wastewater use in irrigated agriculture: confronting the livelihood and environmental realities. (pp 25-40) IWMI/IDRC-CRDI/CABI, Wallingford, UK

Cakmak, B \& Apaydin, H. (2010). Review: Advances in the management of the wastewater in Turkey: Natural treatments or constructed wetlands. Spanish Journal of Agricultural Research 8(1): 188-201. Available online at www.inia.es/sjar

Carr, G. and Potter, R. B. (2013). Towards effective water reuse: drivers, challenges and strategies shaping the organizational management of reclaimed water in Jordan. The Geographical Journal, 179(1), 61-73. doi: 10.1111/j.1475- 4959.2012.00478.x

Carr, G., Nortcliff, S. and Potter, R. B. (2010) Water reuse for irrigated agriculture in jordan: challenges of soil sustainability and the role of management strategies. Philosophical Transactions of the Royal Society 368:5315-5321.

Eaton, A.D., Clesceri, L.S., Rice, E.W. and Greenberg, A.E. eds (2005). Standard methods for examination of water and wastewater, $21^{\text {st }} \mathrm{edn}$. American Public Health Association, American Water Works Association, Water Environment Federation. Washington, USA.

Elder J. 2009. PSY6130 Multiple Comparisons: Lecture 17 Summary. York University. Available at: https://www.slideserve.com/diza/psyc-6130. [Accessed: 28 June 2019]

Ghasemi, A. and Zahediasl, S. (2012). Normality tests for statistical analysis: A guide for non-statisticians. International Journal of Endocrinology Metabolism. 10(2): 486-489. doi: 10.5812/ijem.3505

Hach Company (1992). Water analysis handbook, $2^{\text {nd }}$ edn. Hack company,USA.

Hespanhol, I. (1997). Wastewater as a resource. In: Helmer, R and Hespanhol, I. (eds). Water pollution control a guide to the use of water quality management principles. E \& FN Spon, London

Hussain I., Raschid, L., Hanjra, M.A., Marikar, F. and Van der Hoek, W. (2002). Wastewater use in agriculture: Review of impacts and methodological issues in valuing impacts. Working Paper 37. Colombo, Sri Lanka: International Water Management Institute.

Jiménez, B. (2006) Irrigation in developing countries using wastewater. International Review for Environmental Strategies, 6(2):229-50

Kaluli, J. W., Githuku, C., Home P. and Mwangi, B.M. (2011). Towards a national policy on wastewater reuse in kenya. Policy on wastewater. JAGST, 13(1): 116-125

Karanja, P.M. (2015). Suitability of waste water sludge for agricultural use: a case study of Ruai sewage treatment plant, Nairobi, Kenya. (Master thesis), Kenyatta University, Kenya

Keremane, G. B. and Mckay, J. (2006). Successful wastewater reuse scheme and sustainable development: a case study in Adelaide. Wastewater reuse and sustainable development. 21(2):83-91. doi:10.1111/j.17476593.2006.00062.x.

Kihila, J., Mtei, K.M., and Njau, K.N. (2014). Wastewater treatment for reuse in urban agriculture; the case of Moshi Municipality, Tanzania. Physics and Chemistry of the Earth, 72-75 (2014):104-110.

Koffi, K.M., Coulibaly, S., Atse, B.C and Kouamelan, E. P. (2014). Survey of heavy metals concentrations in water and sediments of the estuary Bietri Bay, Ebrie Lagoon,Cote D'ivoire. International Journal of Research in Earth \& Environmental Sciences. 1(3): 1-10. Available from: http://www.ijsk.org/ijrees.htm

Laurenson, S., Bolan, N.S., Smith, E. and Mccarthy, M. (2012) Review: Use of recycled wastewater for irrigating 
grapevines. Australian Journal of Grape and Wine Research 18: 1-10 doi: 10.1111/j.17550238.2011.00170.x

Lenntech, (2009). Water recycling for agricultural use. Available: http://www.lenntech.com [Accessed on $31^{\text {st }}$ December, 2017]

Mahjoub, O., Mekada, M. and Gharbi, N. (2016). Good irrigation practices in the wastewater irrigated area of Ouardanine, Tunisia. In: Hettiarachchi, H. and Reza Ardakanian, R. (eds). Safe use of wastewater in agriculture: good practice examples UNU-FLORES, pp:101-120.

Mara, D. (2001). Appropriate wastewater collection, treatment and reuse in developing countries. Proceedings of the Institution of Civil Engineers Municipal Engineer 145 December 2001 Issue 4. pp: 299-303.

Martinez, C.J. and Clark, M.W. (2015) Using reclaimed water for landscape irrigation. Series AE449. Agricultural and Biological Engineering Department,UF/IFAS Extension, University of Florida, US. Available at: http://edis.ifas,ufl.ed (Accessed: 2 May 2016)

Mathenge, S.G. (2013). Assessment of selected antibiotics and heavy metals in untreated wastewater, vegetables and soils in eastern Nairobi, Kenya. (Doctoral Thesis), Kenyatta University, Kenya.

McDonald, J.H. (2014). Handbook of biological statistics (3rd edn.) Sparky House Publishing, Baltimore, Maryland.

Mireri, C., Latema, S. and Majale, C. (2007).Water and sanitation delivery in Kenya. In: Waswa, F. (Ed), Environment and sustainable development: A guide for higher education in Kenya 2: 275-281, Kenyatta University, Nairobi.

[NCWSC] Nairobi City Water and Sewerage Company (2015). Waste water treatment process. Available at: http://www.nairobiwater.co.ke/index.html [Accesses on 31 March 2015]

Njagi, J. M. (2013). Assessment of heavy metal concentration in the environment and perceived health risks by the community around Kadhodeki dumpsite, Nairobi County. (Doctoral Thesis), Kenyatta University, Kenya

Nolan, S. A. and Heinzen, T.E. (2011). Essentials of statistics for the behavioural science. Worth publishers, New York, USA.

Norušis, M. J. (2008). SPSS 16.0 guide to data analysis. Upper Saddle River, N.J. 07458: Prentice Hall, Inc.

Nzeve, J.K. (2015). Assessment of heavy metal contamination in Masinga reservoir, Kenya. (Doctoral Thesis) Kenyatta University, Kenya.

Oyebode, O.J. (2015). Effective management of wastewater for environment, health and wealth in Nigeria. International Journal of Scientific \& Engineering Research, 6(7): 1028-1059.

Öztuna, D., Elhane, A.H. and Tüccar, R. (2006). Investigation of four different normality tests in terms of type 1 error rate and power under different distributions. Turkish Journal of Medical Sciences; 36 (3): 171-176.

Panchagnula, S. (2016). Estimation of nitrates in water sample by colorimetry and potentiometry - a comparitive study. International Journal of Trend in Research and Development, 3(2):226-227 www.ijtrd.com

Pescod, M.B. (1992). Wastewater treatment and use in agriculture. FAO Irrigation and Drainage Paper No. 47. UN, Rome.

Pfleiderer, S. Englisch, M. \& Reiter, R. (2012). Current state of heavy metal contents in Vienna soils. Environmental Geochemistry and Health. 34(6): 665-675. https://doi.org/10.1007/s10653-012-9485-8

Pitt, R. (2007). Water sample collection methods. http://unix.eng.ua.edu/. [Accessed 2 March 2019]

Raja, S., Cheema, H.M.N., Babar, S., Khan,A.A., Murtaza, G., and Aslam, U. (2015). Socio-economic background of wastewater irrigation and bioaccumulation of heavy metals in crops and vegetables. Agricultural Water Management, 158: 26-34. doi.org/10.1016/j.agwat.2015.04.004 0378-3774

Rageh, A. (2014). Impacts assessment of reclaimed wastewater use in agriculture irrigation in Amran area, republic of Yemen. International Journal of Environment and Sustainability 3(1):7-13 Available at: www.sciencetarget.com

Raschid-Sally, L., Bradford, A. M. and Dominic, D. (2004). Productive use of wastewater by poor urban and periurban farmers: Asian and African case studies in the context of the Hyderabad Declaration on wastewater use, In: Moriarty, P., Butterworth, J. and van Koppen, B. (eds). Beyond domestic: Case studies on poverty and productive uses of water at the household level. IRC International Water and Sanitation Centre. Technical Paper Series; no. 41, (pp 95-113). Delft, the Netherlands

Razali, N. M. and Wah, Y.B. (2011). Power comparisons for Shapiro-Wilk, Kolmogorov-Smirnov, Lilliefors and Anderson-Darling tests. Journal of Statistical modelling and Analytics. 2(1):21-33. Available at: https://www.researchgate.net/publication/267205556_Power_Comparisons. (Accessed: 23 May 2019).

Salkind, N.J. (Ed). (2007). Encyclopedia of measurement and statistics, Vol. 2. Thousand Oaks, California 91320: SAGE.

Scheierling SM, Barton C, Mara DD, Drechsel P. (2010). Improving wastewater use in agriculture: an emerging priority. (Policy Research working paper; no. WPS 5412). Washington, DC: World Bank. Available at: http://documents.worldbank.org/curated/en/710411468176653818/. [Accessed: 1 September 2016]

Sewe, H., Njenga, J., Oyaro, N., Mailutha, J.T. and Makayoto, M. (2013). The efficiency of dandora domestic and 
industrial waste treatment plant Nairobi, Kenya. Journal of the Kenya Chemical Society 7(1): 40-49. Available from: http://ir.jkuat.ac.ke/

Shayib MA. 2013. Applied statistics $1^{\text {st }}$ Ed. [place unknown]: [Publisher unknown]. Available from: http://bookboon,com.

Shomar, B. and Dare A. (2015). Ten key research issues for integrated and sustainable wastewater reuse in the Middle East. Environmental Science and Pollution Research 22:5699-5710. Doi: 10.1007/s11356-014-38757

Sigoria, E. N. (2012). Heavy metal pollution in red haricot beans (phaseolus vulgaris) and cowpeas (vigna unguiculata) grown using untreated sewage water in Ruai, Nairobi - Kenya. [master's Thesis], Kenyatta University. Kenya

Van der Hoek, W.; Ul Hassan,M.; Ensink, J. H. J.; Feenstra, S.; Raschid-Sally, L.; Munir, S.; Aslam, R.; Ali, N.; Hussain, R.and Matsuno, Y. (2002). Urban wastewater: A valuable resource for agriculture. A case study from Haroonabad, Pakistan. Research Report 63. Colombo, Sri Lanka: International Water Management Institute.

Van Lier, J. B. and Huibers, F. P. (2010). From unplanned to planned agricultural use: making an asset out of wastewater. Irrigation Drainage System 24:143-152.

[WSP and IWMI] Water and Sanitation Program and International Water Management Institute (2016). Recycling and reuse of treated wastewater in urban India: a proposed advisory and guidance document. Colombo, Sri Lanka: International Water Management Institute (IWMI). CGIAR Research Program on Water, Land and Ecosystems (WLE). doi:10.5337/2016.203

\section{Appendix A}

Table A.1: Results of Shapiro-Wilk Tests of Normality

\begin{tabular}{|c|c|c|c|c|c|c|c|c|c|}
\hline \multirow{2}{*}{\multicolumn{2}{|c|}{$\begin{array}{c}\text { Parameter } \\
\text { \& Site }\end{array}$}} & \multicolumn{3}{|c|}{ Shapiro-Wilk } & \multicolumn{2}{|c|}{ Parameter \& Site } & \multicolumn{3}{|c|}{ Shapiro-Wilk } \\
\hline & & \multirow{2}{*}{$\frac{\text { Statistic }}{.926}$} & \multirow{2}{*}{$\frac{\text { df }}{6}$} & \multirow{2}{*}{$\frac{p \text {-value }}{.546}$} & \multirow[b]{2}{*}{ TS } & \multirow[b]{2}{*}{$\mathrm{A}$} & \multirow{2}{*}{$\begin{array}{c}\text { Statistic } \\
.948\end{array}$} & \multirow{2}{*}{$\begin{array}{c}\mathbf{d f} \\
8\end{array}$} & \multirow{2}{*}{$\frac{p \text {-value }}{.691}$} \\
\hline $\mathrm{Cd}$ & $\mathrm{A}$ & & & & & & & & \\
\hline & $\mathrm{B}$ & .883 & 6 & .281 & & $\mathrm{~B}$ & .974 & 8 & .929 \\
\hline & $\mathrm{C}$ & .854 & 6 & .169 & & $\mathrm{C}$ & .945 & 8 & .658 \\
\hline \multirow[t]{3}{*}{$\mathrm{Cr}$} & $\mathrm{A}$ & .837 & 5 & .157 & Chlorides & A & .949 & 8 & .702 \\
\hline & $\mathrm{B}$ & .750 & 3 & .000 & & $\mathrm{~B}$ & .811 & 8 & .037 \\
\hline & $\mathrm{C}$ & .980 & 3 & .727 & & $\mathrm{C}$ & .942 & 8 & .628 \\
\hline \multirow[t]{3}{*}{$\mathrm{Cu}$} & A & .943 & 3 & .538 & $\mathrm{pH}$ & $\mathrm{A}$ & .927 & 8 & .488 \\
\hline & $\mathrm{B}$ & .963 & 3 & .630 & & $\mathrm{~B}$ & .916 & 8 & .396 \\
\hline & $\mathrm{C}$ & .750 & 3 & .000 & & $\mathrm{C}$ & .930 & 8 & .519 \\
\hline \multirow[t]{3}{*}{$\mathrm{Fe}$} & $\mathrm{A}$ & .971 & 6 & .899 & COD & $\mathrm{A}$ & .967 & 8 & .874 \\
\hline & $\mathrm{B}$ & .941 & 6 & .664 & & $\mathrm{~B}$ & .889 & 8 & .228 \\
\hline & $\mathrm{C}$ & .966 & 6 & .862 & & $\mathrm{C}$ & .969 & 8 & .889 \\
\hline \multirow[t]{3}{*}{$\mathrm{Pb}$} & $\mathrm{A}$ & $\mathrm{n} / \mathrm{a}$ & & & BOD & $\mathrm{A}$ & .969 & 7 & .894 \\
\hline & $\mathrm{B}$ & $\mathrm{n} / \mathrm{a}$ & & & & $\mathrm{B}$ & .729 & 7 & .008 \\
\hline & $\mathrm{C}$ & .743 & 4 & .033 & & $\mathrm{C}$ & .956 & 7 & .787 \\
\hline \multirow[t]{3}{*}{$\mathrm{Ni}$} & $\mathrm{A}$ & .972 & 6 & .903 & Nitrates & $\mathrm{A}$ & .798 & 4 & .100 \\
\hline & $\mathrm{B}$ & .895 & 6 & .347 & & $\mathrm{~B}$ & .831 & 4 & .170 \\
\hline & $\mathrm{C}$ & .842 & 5 & .169 & & $\mathrm{C}$ & .780 & 4 & .071 \\
\hline \multirow[t]{3}{*}{$\mathrm{Mn}$} & $\mathrm{A}$ & .724 & 6 & .011 & Phosphates & $\mathrm{A}$ & .784 & 6 & .042 \\
\hline & $\mathrm{B}$ & .723 & 6 & .011 & & $\mathrm{~B}$ & .935 & 6 & .621 \\
\hline & $\mathrm{C}$ & .943 & 6 & .686 & & $\mathrm{C}$ & .901 & 6 & .380 \\
\hline \multirow[t]{3}{*}{$\mathrm{Zn}$} & $\mathrm{A}$ & .993 & 6 & .996 & $\mathrm{FC}$ & $\mathrm{A}$ & .767 & 6 & .029 \\
\hline & $\mathrm{B}$ & .901 & 6 & .377 & & $\mathrm{~B}$ & .851 & 6 & .161 \\
\hline & $\mathrm{C}$ & .803 & 5 & .086 & & $\mathrm{C}$ & .928 & 6 & .565 \\
\hline \multirow[t]{3}{*}{$\mathrm{K}$} & $\mathrm{A}$ & .832 & 6 & .111 & $\mathrm{TC}$ & $\mathrm{A}$ & .873 & 6 & .240 \\
\hline & $\mathrm{B}$ & .734 & 6 & .014 & & $\mathrm{~B}$ & .754 & 6 & .022 \\
\hline & $\mathrm{C}$ & .754 & 6 & .022 & & $\mathrm{C}$ & .973 & 6 & .912 \\
\hline
\end{tabular}

Note. Sig. level at $\mathrm{p} \leq .05 ; \mathrm{n} / \mathrm{a}=$ levels were below detection limit 


\section{Appendix B}

Table B.1: Kruskal-Wallis H test results showing site and ranks

\begin{tabular}{|c|c|c|c|c|c|c|}
\hline Parameter & Sample 1-Sample 2 & $\begin{array}{c}\text { Test } \\
\text { Statistic }\end{array}$ & Std. error & Std. Test statistic & Sig. & Adj. Sig \\
\hline \multirow{3}{*}{$\mathrm{Pb}$} & Site C-site B & 3.000 & 2.109 & 1.423 & .155 & .464 \\
\cline { 2 - 7 } & Site C-site A & 5.000 & 2.109 & 2.371 & .018 & .053 \\
\cline { 2 - 7 } & Site B-site A & 2.000 & 2.435 & .821 & .411 & 1.000 \\
\hline \multirow{3}{*}{ BOD } & site A- site C & -2.714 & 3.310 & -.820 & .412 & 1.000 \\
\cline { 2 - 7 } & site A- site B & -8.643 & 3.310 & -2.611 & .009 & .027 \\
\cline { 2 - 7 } & site C- site B & 5.929 & 3.310 & 1.791 & .073 & .220 \\
\hline \multirow{2}{*}{ FC } & Site A-site B & -2.167 & 3.066 & -.707 & .480 & 1.000 \\
\cline { 2 - 7 } & Site A-site C & -10.083 & 3.066 & -3.288 & .001 & .003 \\
\cline { 2 - 7 } & Site B-site C & -7.917 & 3.066 & -2.582 & .010 & .029 \\
\hline
\end{tabular}

Table B.2: Kruskal-Wallis results of pairwise comparisons

\begin{tabular}{|c|c|c|c|c|c|c|c|}
\hline Parameter & Site & $\mathbf{N}$ & Mean Rank & Parameter & Site & $\mathbf{N}$ & Mean Rank \\
\hline \multirow{3}{*}{$\mathrm{Cr}$} & $\mathrm{A}$ & 5 & 6 & \multirow{3}{*}{ Chlorides } & $\mathrm{A}$ & 8 & 10.00 \\
\hline & B & 3 & 6.67 & & B & 8 & 13.88 \\
\hline & $\mathrm{C}$ & 3 & 5.33 & & $\mathrm{C}$ & 8 & 13.63 \\
\hline \multirow{3}{*}{$\mathrm{Cu}$} & A & 3 & 4.33 & \multirow{3}{*}{$\mathrm{pH}$} & $\mathrm{A}$ & 8 & 19.63 \\
\hline & $\mathrm{B}$ & 3 & 5.17 & & $\mathrm{~B}$ & 8 & 10.5 \\
\hline & $\mathrm{C}$ & 3 & 5.5 & & $\mathrm{C}$ & 8 & 7.38 \\
\hline \multirow{3}{*}{$\mathrm{Pb}$} & A & 2 & 7.5 & \multirow{3}{*}{ Phosphates } & $\mathrm{A}$ & 6 & 10.08 \\
\hline & $\mathrm{B}$ & 2 & 5.5 & & B & 6 & 10.33 \\
\hline & $\mathrm{C}$ & 4 & 2.5 & & $\mathrm{C}$ & 6 & 8.08 \\
\hline \multirow{3}{*}{$\mathrm{Mn}$} & A & 6 & 9.5 & \multirow{3}{*}{$\mathrm{FC}$} & A & 6 & 5.42 \\
\hline & B & 6 & 6.5 & & B & 6 & 7.58 \\
\hline & $\mathrm{C}$ & 6 & 12.5 & & $\mathrm{C}$ & 6 & 15.5 \\
\hline \multirow{3}{*}{$\mathrm{K}$} & $\mathrm{A}$ & 6 & 8.17 & \multirow{3}{*}{$\mathrm{TC}$} & A & 6 & 10.42 \\
\hline & $\mathrm{B}$ & 6 & 10 & & $\mathrm{~B}$ & 6 & 9.00 \\
\hline & $\mathrm{C}$ & 6 & 10.33 & & $\mathrm{C}$ & 6 & 9.08 \\
\hline \multirow{3}{*}{ BOD } & $\mathrm{A}$ & 7 & 7.21 & & & & \\
\hline & B & 7 & 15.86 & & & & \\
\hline & $\mathrm{C}$ & 7 & 9.93 & & & & \\
\hline
\end{tabular}

Note. 1. Each row tests the null hypothesis that the sample 1 and sample 2 distributions are the same,

2 . The significance level is .05 . 